\title{
Women's Pleasure Online? A Contrasting Analysis of One Japanese Mainstream and One Women's Pornographic Film from the Internet
}

\author{
Katharina Helm
}

\begin{abstract}
This paper introduces the results of a two-stage analysis of one Japanese mainstream and one women's pornographic film from the Internet, asking whether any differences between the gender representations of both sexes can be observed, and whether these differences correspond to the films' Western counterparts. In the first stage, the films are being analysed regarding their correspondence to characteristics of mainstream pornography and, respectively, criteria of women's pornography, which were developed through Western feminists' debates. The detailed case studies of the two films that were selected as examples deal with their general and sexual contents, aesthetic elements, dialogues, and the appearance of the characters. In the second stage, the gender roles are being examined. The analysis firstly confirms that both films correspond to their Western counterparts and that they contain substantial differences concerning contents, aesthetic elements, dialogues, and the quality of the displayed relationship of the characters. Secondly, the paper shows that the gender representations in the mainstream pornographic film stick to conventional gender roles related to this genre, with an emphasis on male-centered sexual practices, which are linked to the female body's objectification. By contrast, the women's pornographic film features-besides female-friendly sexual practices-non-sexual aspects of the relationship between the characters and introduces an alternative male role model.
\end{abstract}

Keywords: film analysis, Japanese mainstream pornography, Japanese women's pornography, gender roles, PorNo and PorYes feminism

Helm, Katharina. "Women's Pleasure Online? A Contrasting Analysis of One Japanese Mainstream and One Women's Pornographic Film from the Internet." In Vienna Journal of East Asian Studies, Volume 8, eds. Rudiger Frank, Ina Hein, Lukas Pokorny, and Agnes Schick-Chen. Vienna: Praesens Verlag, 2016, pp. 3364. https://doi.org/10.2478/vjeas-2016-0002 


\section{Introduction}

The usage of the Internet increasingly influences all sorts of individual life's areas, ranging from online banking, shopping, gaming, and ordering food to connecting with an international community of Internet users, finding a partner via online dating platforms, and exchanging diverse information through the World Wide Web. Besides hosting all kinds of businesses, the Internet also serves the fulfilment of personal needs and caters to the users' most intimate spheres: their sexual desires. Within a few clicks, all sorts of sexual desires could be satisfied, not only anonymously but, in many cases, also for free. Numerous homepages supply mainly male viewers with diverse sexual services, such as erotic chats or cybersex via live cams, and they offer a tremendous amount of online pornography. The number of consumers keeps on growing, and the international porn industry's rising profits reflect the popularity of online sex (SS 2015), which is mainly targeting male viewers. Besides the established target group, recently ${ }^{1}$ female viewers have also been discovered as potential porn consumers. Whereas the porn market for female consumers originally was dominated by porn-magazines, lately ${ }^{2}$ female-friendly Internet pornography is on the advance. ${ }^{3}$

According to the international ranking of profiteers from online pornography, Japan is one of the financially most benefiting countries worldwide, although it is hard to find reliable data on this subject (SS 2015). The growing economic and societal effects of online pornography make the urgency of scientific research on these developments more and more obvious. This also concerns the field of Japanese studies. However, although Japanese pornography offers a broad possible research field, most of the scientific work on pornography is related to the Western context; within the scientific discourse about pornography, scholarship from a Japanese studies' perspective can be hardly found. Previous research on Japanese pornography has focused on historical aspects, such as shunga 春画, pornography in the Meiji era, or censorship in post-war Japan. ${ }^{4}$ Jasper Sharp (2008) and Roland Domenig (2002) published scientific studies on Japanese sex film (pinku eiga ピンク映画) and its development within the Japanese film industry, as well as on erotic film genres in general. ${ }^{5}$

1 Feminist porn, which is mainly directed at a female audience, originated in the 1980 s and was introduced to a broader audience starting in 2006, when the Canadian Feminist Porn Awards were established to draw attention to and support female-friendly porn (FPAs 2016).

2 It is hard to tell when women's pornography was published on the Internet for the first time, but the number of homepages that offer women's porn seems to be growing.

3 See Helm 2015: 7-9 for a more detailed account.

4 See Shirakura 2002; Ishiguro 1997; and Cather 2012 respectively.

5 For further information, see Helm 2015: 7-9. 
As the discourse within Japanese studies does not offer an up-to-date approach to newer forms of pornography, such as female-friendly porn, this paper aims at, firstly, describing the typical characteristics of Japanese mainstream and women's pornography from the Internet, ${ }^{6}$ taking two selected films as examples. Secondly, these descriptions shall serve as a foundation for the ensuing contrasting analysis of the construction of gender roles within both films. The underlying research questions are: 1) Does Japanese mainstream pornography and women's pornography correspond to Western characteristics and criteria? 2) What kinds of gender roles of both sexes are being displayed in Japanese mainstream and women's pornography? The two chosen films will be analysed by referring to Western characteristics and criteria, ${ }^{7}$ which have been developed through mainly Western feminists' debates about the pros and cons of pornography since the 1980s. This polarising discussion divided feminists into an anti-pornographic (PorNo) fraction that opposes sexist depictions of especially women in mainstream pornographic films, and a sexpositive (PorYes) fraction that demands new forms of a female-friendly and more diverse pornography regarding the displayed sexual practices, body forms, the story, aesthetic elements, and so forth. In this study, characteristics of mainstream pornography and criteria of women's pornography that developed in the context of these feminist debates will be introduced to serve as an underlying basis ${ }^{8}$ for the film analysis (Helm 2015: 8-13).

Before proceeding, however, the critical question whether it is justified to apply Western characteristics and criteria to Japanese films must be addressed. Firstly, characteristics of mainstream pornography and criteria of women's pornography within the Japanese context have not yet been identified to serve as a possible basis for analysis, which makes it necessary to provisionally operate with the established Western ones. After carefully examining Japanese pornographic films from the Internet, it turned out that Japanese mainstream and women's pornography show many similarities with their Western counterparts. ${ }^{9}$ Secondly, there cannot be found considerable differences between Western and Japanese feminists' debates on pornography, which makes it possible to apply the characteristics and criteria identified by Western feminists to serve for the analysis of Japanese pornography (ibid.: 13-14).

6 This analysis focuses on heterosexual pornographic films and does not discuss homosexual or fetish porn.

7 Mainstream pornography can be described by characteristics that differentiate it from other genres. Women's pornography, on the other hand, can be described by criteria (differentiating characteristics) that also represent preconditions, formulated by Western feminists.

8 The western characteristics and criteria will be introduced below, in the section "Film Analysis".

9 More detailed explanations on similarities and differences between Western and Japanese mainstream and women's pornographic films will be given later in this paper, starting with the section "Analysis of a Japanese Mainstream Pornographic Film”. 
The analysis will be conducted in two stages: First, the films will be analysed ${ }^{10}$ regarding their general and the sexual contents, the aesthetic elements (such as sound/music, setting, and camera work), the dialogues, and the characters. Second, the gender roles that are displayed in the two genres will be examined and contrasted against each other, in order to highlight the differences (ibid.: 12).

\section{About Film Genres and Feminist Debates About Pornography}

\section{Erotic Film Genres, Pinku Eiga, and Japanese Hardcore Pornography}

Before introducing Japanese hardcore pornography (adaruto bideo アダルト・ ビデオ, adult video/AV) and Japanese sex film (pinku eiga), basic theoretical distinctions between the genres erotic film, sex film, and hardcore pornography need to be explained. These three genres are often summarised under the term 'erotic film' and share their focus on erotic and/or sexual contents, whereas differences regarding the explicitness of the depiction can be found. Erotic films show the least sexual content, followed by sex films (also called 'soft porn') that only show simulated sex. The most explicit depictions of real sex are displayed in hardcore pornography (Faulstich 2013: 32, 56-58), which is this present analysis' object.

Concomitant with the extent of the explicitness of erotic and/or sexual contents, differences amongst the aesthetics, the narration, and the productions' conditions can also be identified: For example, in hardcore pornography, the bodies are strongly neglected and the focus on the depiction of genitalia dominates the shots' contents, the narration plays a secondary role, and the quality of the production is low, compared to the other two genres. Further, the sexual act is being displayed in a very detailed and concrete way, the dialogues are simple and reduced to the most basic conversation, characters have no deeper psychological dimension and are interchangeable, scenes displaying sexual actions follow one another seamlessly, and sounds as well as music are intended to support the sexual contents of the film by: 1) putting an emphasis on moans of pleasure; 2) later synchronising the moaning voices in the studio; and 3) choosing rhythmical music that fits the physical movements (Stiglegger 2009: 2; Faulstich 2013: 56-60).

Faulstich describes hardcore pornography as a depiction of sexual contents in a written, visual, or acoustic way which is 'explicitly detailed, scenic narrative and fictionally real' (1994: 33). According to this definition, hardcore pornography differs from real sexuality as it is narrated and therefore fictional, and it differs from eroticism as it shows sexual contents in a detailed and explicit way (ibid.). Further,

10 Detailed data about sequences and shots of the selected pornographic films can be found in the Appendix of my M.A. thesis (Helm 2015: 114-158, and tables 6-7). 
hardcore pornography aims at creating sexual stimulation to the viewers. As male viewers are the target group of heterosexual mainstream pornography (the most widely spread form of hardcore pornography), female characters are depicted as sexually willing objects. The sexual act itself is rude, vulgar, and crude, and characters appear to be solely driven by their lust (Faulstich 2013: 60).

Like other forms of media, hardcore pornography has developed in time and newer forms have emerged. Alternative porn, post porn, and hentai 変態 porn are some examples. The subgenre of alternative porn aims at supplying consumers with a more diversified range of body types, including characters with tattoos, piercingsm and/or alternative looks/styles - like emo or nerd (Bateman 2007). Post porn is a politically motivated genre that questions established forms of sexuality and conventional sexual identities (MM 2013). Hentai porn originated in Japan and can be described as animated film (anime アニメ) or comic (manga 漫画) with sexual content (Helm 2015: 22-23).

Since the early 1960s, soft porn productions called pinku eiga flourished in Japan. Although these are sex but not porn films, they are classified as seijin eiga (成人映画, films for adults) and hold the British R 18 certificate, which labels porn films. In fact, pinku eiga do not show any genitalia or real sex. These sex films have an average duration of one hour and are being presented in Japanese adult cinemas, where tickets are sold in threes (sanbondate 3 本立て). Although pinku eiga are stereotyped as being produced inexpensively, the productions' costs as well as the contents, the quality, and the aesthetic design vary greatly (Sharp 2008: 9-10, 1213). Pinku eiga's first introduction was at a time when television was being established in Japanese private homes, which led to a decline in the numbers of cinemagoers. Japanese film studios suffered financially from sales' shortages. Independent film producers got the opportunity to sell their cheaply produced sex films on the crisis-ridden cinema market (Domenig 2002). Within only a few years since the first emergence of pinku eiga, this cinema genre became popular and prospered in Japan (Sharp 2008: 9-10).

Until the 1980s, the production of pinku eiga was a lucrative business, but with the import of Western porn videos and the spread of the video industry sales' numbers started declining. Many producers of pinku eiga joined the newly established porn video industry, which also forced back the established sex film production (Domenig 2002). Whereas in the 1980s Western porn videos had been imported illegally due to the uncensored sexual contents, shortly afterwards the domestic market started to produce and sell its own pornographic films, which became an enormously profitable business. Japanese productions that show sexual contents are subject to censorship, which makes it necessary to blur genitalia and pubic areas (ibid.). Besides porn films, diverse pornographic productions such as books, magazines, and comics are sold, serving all sorts of sexual fantasies and fetishes (Uchiyama and Diamond 1999). 


\section{Feminist Ideologies on Pornography: PorNo and PorYes}

To be able to compare mainstream pornography with women's pornography ${ }^{11}$ it is crucial to understand the distinguishing characteristics and criteria of these two genres, which derived from mainly Western feminists' debates about the pros and cons of pornography. Therefore, in this section the arguments of pornography's proponents and opponents will be summarised.

Radical PorNo feminism emerged in the 1970s in the USA, speaking out against mainstream pornography, which displays violence towards women (Hahn 2011: 21). This is one of the most important arguments brought up by radical feminists in the controversial debates about pornography. According to them, mainstream pornography supports abusive, violent, degrading, and oppressive behaviour towards women and, therefore, should be censored or prohibited (Dworkin 1987: 134-135, 138-139, 144, 147; Helm 2015: 27). Furthermore, PorNo feminists state that female characters in mainstream pornography are being forced into a subordinate state ${ }^{12}$ by taking over the role of an object/victim, while male characters are acting as subjects/perpetrators, which mirrors the patriarchal structure of society (Hahn 2011: 27; Ferguson et al. 1984: 108-109). Moreover, misogynistic mainstream pornography might create a link between violence and sexuality as, according to the German feminist Alice Schwarzer (b. 1942), male viewers are being socialised by their porn consumption (1994: 14-16, 37), which has a great impact on women's real lives. Many radical PorNo feminists criticise not only hardcore porn, but also soft porn, as this gender bias is the same overall (ibid.: 35). The debate amongst American PorNo feminists set off a worldwide discussion about pornography and its negative influences. Some of the most important representatives of radical PorNo feminism are Catherine A. MacKinnon (b. 1946) and Andrea Dworkin ${ }^{13}$ (b. 1946) as leading figures of the American movement, and Alice Schwarzer, founder and editor of the German feminist magazine Emma, as figurehead of the German movement.

By contrast, in the 1980s, sex-positive PorYes feminists united to oppose the American PorNo feminists' demands for censorship and prohibition of pornography. Although PorYes and PorNo feminists both advocate the prohibition of misogynistic and illegal pornography, ${ }^{14}$ sex-positive feminists are against a complete prohibition of hardcore pornography (Hahn 2011: 28-29). In their opinion, mainstream porn should be transformed into sex-positive pornography that respects both sexes in

11 Women's pornography can be described as subgenre of hardcore pornography (Rückert 2000: 101).

12 Female characters are often portrayed as enjoying their subordinate role (which corresponds to the Western characteristics of mainstream pornography's characters), although this is not the case in all mainstream pornographic films. For further information, see Table 3 below.

13 Dworkin describes her radical feminist attitude in Pornography: Men Possessing Women (1979).

14 Child pornography and porn that shows sex with animals, rape, or other forms of sexual violence are prohibited by law in many countries worldwide (Helm 2015: 31). 
order to enrich both men's and women's sexual lives. What is more, PorYes feminists want to prevent sex workers and persons who work in the porn industry from stigmatisation, which might occur due to regressive tendencies like censorship or prohibition (ibid.). According to PorYes feminism, patriarchy is an imposed social system that forces men and women into normative heterosexual relations and discriminates people with other sexual orientations, which is being reflected in mainstream porn. Therefore, new and alternative forms of pornography should serve as field of experimentation for sexual variety that does not exclude sexual minorities (Ferguson et al. 1984: 109).

According to the initiators of the European PorYes Award ${ }^{15}$ 'the answer to bad porn is not no porn but better porn' (PYA n.y.c). This motto summarises the convictions of sex-positive feminists who strive for female-friendly, sexually diverse, and gender equal pornography (PYA n.y.a). Initiatives like the PorYes Award support the production of feminist porn that especially considers female consumers' desires, which are suppressed in mainstream pornography (PYA n.y.a). Therefore, a wide range of criteria serves as a basic guideline for feminist films' productions, of which the three most important ones shall be introduced here briefly: 1) all characters' lust should be displayed in a sex-positive way; 2) the film should reflect sexual diversity; and 3) women should be involved in the film production to secure women-friendly results (PYA m.y.b). The PorYes Award exemplarily mirrors sex-positive feminists' efforts to offer alternative forms of pornography that oppose sexist and suppressing mainstream pornography (PYA n.y.b).

The Japanese Women's Liberation Movement (Üman ribu ウーマン・リブ) of the 1960s and 1970s shows many similarities to the American radical feminist movement, which mainly criticised the patriarchal hegemony and its sexism towards women (Dales 2009: 87; Fujieda and Fujimura-Fanselow 1995: 159; Shigematsu 2015: 174). Members of the Women's Liberation Movement demanded a restructuring of societal norms that are the foundation of the discrimination against women. Furthermore, they supported women's sexual freedom (Shigematsu 2015: 174, 176177). Another feminist group, the Women's Action Group (Kōdō suru onnatachi no kai 行動する女達の会), united against sexism and women's discrimination in the media, such as sexist advertisements and other pornographic material that display women in a degrading way (Dales 2009: 87-88). One of their major aims was the censorship of misogynistic depictions of women, which ideologically overlaps with Western radical PorNo feminism. Besides these movements, more liberal and sex-

15 The PorYes Award was initiated by the first European women-oriented sex-company and communicationcentre Sexclusivitäten and the network Freudenfluss in 2009 (PYA n.y.a). The jury consists of five sexpositive feminists: Ula Stöckl, Claudia Gehrke, Laura Méritt, Corinna Rückert, and Margaret von Schiller (PYA n.y.d). 
positive feminist attitudes can be also found in the Japanese context, which are similar to their Western pedants (Dales 2009: 88).

\section{Film Analysis}

\section{Characteristics and Criteria}

Below, the Western characteristics of mainstream pornography and Western criteria of women's pornography are introduced. Tables 1 and 2 offer an overview of all main aspects regarding the genres' contents (divided into concept and production, story and sexual practices).

Table 1 Characteristics of mainstream pornography's contents

\begin{tabular}{|c|c|c|}
\hline \multicolumn{3}{|c|}{ Mainstream Pornography's Contents } \\
\hline Concept and Production & Story & Sexual Practices \\
\hline $\begin{array}{l}\text { reduced context: concrete and } \\
\text { explicit contents, contents are stage- } \\
\text { managed, characters are interchange- } \\
\text { able, depersonalised and being } \\
\text { reduced to their sexual functions, the } \\
\text { characters and the story have no } \\
\text { psychological dimension, }{ }^{6} \text { genitalia } \\
\text { and sexual practices are visible, } \\
\text { ejaculation is visible (money shot) } \\
\text { and ends the film or film sequence } \\
\text { structuring: the viewers' attention is } \\
\text { being drawn to sexual contents } \\
\text { aesthetics: crudeness, roughness, } \\
\text { nastiness } \\
\text { editing: cut out of failed scenes (e.g. } \\
\text { erectile problems) } \\
\text { camera work and perspectives: male } \\
\text { character plays the subject, female } \\
\text { character plays the object }\end{array}$ & $\begin{array}{l}\text { there is no } \\
\text { story/narration; } \\
\text { merely sexual } \\
\text { contents are shown, } \\
\text { introduction } \\
\text { sequence serves as } \\
\text { initiator for } \\
\text { sexual contents } \\
\text { aesthetics: } \\
\text { characters show a } \\
\text { lack of restraint } \\
\text { concerning their } \\
\text { sexual desires } \\
\text { and are } \\
\text { dominated by } \\
\text { their lust }\end{array}$ & $\begin{array}{l}\text { women's } \\
\text { masturbation, } \\
\text { vaginal sex in } \\
\text { diverse } \\
\text { positions, } \\
\text { anal sex, } \\
\text { orgies, } \\
\text { oral sex (mainly } \\
\text { fellatio), } 17 \\
\text { lesbian sex, } \\
\text { ménage à trois } \\
\text { with two women } \\
\text { and one man, } \\
\text { sadomasochism }\end{array}$ \\
\hline
\end{tabular}

Source: Helm 2015: 48

16 Mainstream pornography's characters have no psychological dimension as their gender roles stick to overall sexist clichés that can be described as repetitive throughout the genre. Further, the story is merely focused on sexual actions.

17 Lesbian sex (but not gay sex) within mainstream pornography aims at stimulating the heterosexual male viewers' sexual arousal, whereas lesbian sex and other forms of sexuality within women's pornography are meant to represent sexual plurality. 
Table 2 Criteria of women's pornography's contents

\begin{tabular}{|l|l|l|}
\hline \multicolumn{3}{|c|}{ Women's Pornography's Contents } \\
\hline \multicolumn{1}{|c|}{ Concept and Production } & \multicolumn{1}{|c|}{ Story } & \multicolumn{1}{c|}{ Sexual Practices } \\
\hline two tendencies in the concept: & $\begin{array}{l}\text { story plays } \\
\text { an important } \\
\text { 1) lavish costumes, scenery, and story }\end{array}$ & $\begin{array}{l}\text { sexual plurality, } \\
\text { oral sex (cunnilingus), } \\
\text { 2) natural and reduced depiction } \\
\text { no group sex, no anal } \\
\text { sex-positive attitude, realisation of } \\
\text { diverse fantasies, } \\
\text { individualised characters, } \\
\text { including also non-sexual interactions } \\
\text { between the characters, } \\
\text { focus on women's sexual pleasure, } \\
\text { no stereotypes, } \\
\text { pornographic aspect of the film plays a } \\
\text { subordinate role } \\
\text { production and setting: women's } \\
\text { participation in the production is wanted, } \\
\text { diverse aesthetic elements, diverse } \\
\text { camera perspectives, } \\
\text { authentic music and sound (e.g. no } \\
\text { artificial moans of pleasure) }\end{array}$ \\
\hline
\end{tabular}

Source: Helm 2015: 52

When comparing these characteristics and criteria, many differences between the genres become evident. Women's pornography's contents are based on a story and also contain non-sexual interactions, such as interpersonal dialogues. Furthermore, they display sexual variety. Contrary to this, mainstream porn is dominated by its pornographic character, and sexual practices follow a stereotypical scheme. Both genres' aesthetics differ regarding conceptual, ideological, and technical aspects. There exist qualitative distinctions concerning the production, the setting, and the camera work: Genitalia and pubic areas are focused one-sidedly in mainstream pornography, whereas in women's porn the camera work is more differentiated (Helm 2015: 52-53). By editing mainstream porn's contents after its production, failed scenes by possibly occurring erectile dysfunction can be deleted, which creates the forged impression of unfailing bodies (Flaßpöhler 2007: 208).

Mainstream porn targets male viewers and their sexual desires. Therefore, the male character's lust and (visible) ejaculation play a major role. Women's porn is directed at female viewers and focuses on women's lust and sexual fantasies, while trying not to employ and reinforce stereotypes regarding the characters' gender roles or sexual contents that are common in mainstream porn. Rough sexual practices such as group sex, anal sex, and orgies tend to be displayed in mainstream porn, whereas these practices are being avoided in women's porn (Helm 2015: 52-53). 
Table 3 shows characteristics and criteria of character depiction in both genres (divided into male and female characters, their behaviour, and their appearance):

Table 3 Mainstream and women's pornography's characters

\begin{tabular}{|c|c|c|c|}
\hline \multicolumn{4}{|c|}{ Mainstream Pornography's Characters } \\
\hline \multicolumn{2}{|c|}{ Male Characters } & \multicolumn{2}{|c|}{ Female Characters } \\
\hline Appearance & Behaviour & Appearance & Behaviour \\
\hline $\begin{array}{l}\text { clean-shaven } \\
\text { pubic area }\end{array}$ & $\begin{array}{l}\text { dominant, oppres- } \\
\text { sive behaviour } \\
\text { the ejaculation is } \\
\text { the center of } \\
\text { attention; the } \\
\text { ejaculation takes } \\
\text { place on the } \\
\text { female body, } \\
\text { fully functioning } \\
\text { and lust-driven } \\
\text { body }\end{array}$ & $\begin{array}{l}\text { long hair, } \\
\text { slim, } \\
\text { Caucasian, }{ }^{18} \\
\text { young ( }<30 \text { years), } \\
\text { breast implants, } \\
\text { lingerie and high } \\
\text { heels, } \\
\text { make-up, } \\
\text { clean-shaven pubic } \\
\text { area }\end{array}$ & $\begin{array}{l}\text { naturally lecher- } \\
\text { ous } \\
\text { behaviour: lust, } \\
\text { lechery, sexual } \\
\text { willingness, } \\
\text { sexual } \\
\text { availability, } \\
\text { female orgasm is } \\
\text { secondary, } \\
\text { fully functioning } \\
\text { and lust-driven } \\
\text { body }\end{array}$ \\
\hline \multicolumn{4}{|c|}{ Women's Pornography's Characters } \\
\hline \multicolumn{2}{|c|}{ Male Characters } & \multicolumn{2}{|c|}{ Female Characters } \\
\hline Appearance & Behaviour & Appearance & Behaviour \\
\hline $\begin{array}{l}\text { naturalness and } \\
\text { plurality of } \\
\text { body } \\
\text { types }\end{array}$ & $\begin{array}{l}\text { no focus on erect } \\
\text { penis (the penis is } \\
\text { also shown in } \\
\text { non-erect condi- } \\
\text { tion) }\end{array}$ & $\begin{array}{l}\text { naturalness and } \\
\text { plurality of body } \\
\text { types }\end{array}$ & $\begin{array}{l}\text { women's active } \\
\text { participation is } \\
\text { wanted, } \\
\text { women's } \\
\text { sexual desires are } \\
\text { being focused }\end{array}$ \\
\hline
\end{tabular}

Source: Helm 2015: 49, 52

Mainstream porn's characters have clean-shaven pubic areas and the female character corresponds to a stereotypical ideal of beauty: In Western productions, she is mostly Caucasian, young (under 30 years old), slim, and dressed up in lingerie and high heels - to name only some of the visual attributes. Furthermore, the female character is displayed as being naturally lecherous and sexually willing. In contrast to this, female as well as male characters in women's pornography represent diverse body types with a natural appearance. The women's porn's female character takes over an active part by showing sexual initiative and the male character is not being reduced to his erect penis, unlike his mainstream pornography's counterpart (Helm 2015: 49, 52).

18 While in Western mainstream pornography characters tend to be Caucasian, in Japanese mainstream and women's pornography they are Japanese. 


\section{Film Selection}

Choosing online pornographic films as primary sources for research requires browsing through many pornographic websites to categorise what they offer. Viewing mainstream pornographic films might overtax the viewer when a selection must be made for an analysis, as the range of contents is infinite. After endless hours of investigation, it became more and more apparent that choosing a representative mainstream pornographic film was impossible, if no clear focus regarding the contents is being set in advance. At the same time, however, women's pornographic films are not only limited by numbers but also by their variety. Therefore, it seemed practical to decide on a women's pornographic film first, subsequently using it as a basis to search for a comparable mainstream pornographic film (Helm 2015: 54-55).

Examining websites offering women's pornographic films in a more detailed way it became evident that women's porn, which fulfils all Western criteria explained above, could be hardly found. Many of these films seemed to belong to the subgenre of women's pornography and differ from mainstream pornography regarding their aesthetic design, although sexual practices tended to be still stereotypical. Because they only added elements such as music and dialogues, these films neither could be described as 'women's' nor as mainstream porn. However, some films which matched the criteria could be found, one of them being First Touch (2012), available on the website H.Net Free Porn Videos for Girls. ${ }^{19}$ The website was launched in 2013 and around 100 films are being uploaded monthly. ${ }^{20}$ First Touch was produced by the film production company Silk Labo, which focuses on the production of women's pornography (Helm 2015: 54-55).

I chose this forty minutes long film as an example of a women's pornographic film for closer analysis. Next, a comparable mainstream pornographic film needed to be selected. In terms of comparability aspects such as the general and the sexual contents, the characters' constellations, the setting, and the duration of the film have been taken in consideration. Mainstream pornographic films with more than two characters, extreme sexual practices, ${ }^{21}$ exaggerated artificial settings, or films which show obvious sexual degradation (through sexual practices or verbal expressions) or sexual violence have been excluded from the start, although such elements can be often found in mainstream pornography. Considering all these disqualifying factors, the film Japanese schoolgirl in uniform dicked and stuffed in her twat (2014) has been chosen to serve as an example of mainstream porn. Besides of its comparable duration of around 40 minutes and the inclusion of similar sexual practices, it con-

19 The website's target group, aims, contents, and design will be introduced in the section "Female-Friendly Porn on the Internet: H.Net Free Porn Videos for Girls".

20 Numbers of monthly uploads vary. In February 2016, around 100 films had been uploaded (HN 2015).

21 Extreme sexual practices are well established in mainstream pornography and can comprise group sex, rape, sadomasochistic sex, incestuous sex etc. 
tains an equal constellation of characters as well as a comparable setting (ibid.: 55, 57).

All in all, around 50 porn films ${ }^{22}$ from the Internet have been screened with regard to the characteristics of mainstream porn and criteria of women's porn. Concentrating on only two films might bear some limitations; at the same time, though, it seemed reasonable to do so, since the aim of my research was to analyse the gender roles constructed in Japanese pornographic films in a detailed way (ibid.: 5758). It must also be mentioned that this paper focuses on the analysis of the films' contents rather than on their production background.

\section{Analysis of a Japanese Mainstream Pornographic Film}

The 40 minutes long Japanese mainstream pornographic film Japanese schoolgirl in uniform dicked and stuffed in her twat was published in 2014 on the website www.pornhub.com ${ }^{23}$ and was categorised by the terms hardcore, Japanese, and creampie. ${ }^{24}$ Further tags such as amateur, fingering, Asian, brunette, orgasm, squirt, ${ }^{25}$ hairy-pussy, blowjob, doggy-style, busty, and reverse-cowgirl have been used to describe the film in a more detailed way. Unlike Japanese providers, the American website Pornhub is not tied to censorship. Although the title of the selected mainstream porn is English, the contents are Japanese (Helm 2015: 58).

The film is about the sexual encounter of a young Japanese woman, supposedly a schoolgirl, and a middle-aged Japanese man. A room with discreet interior and a bed serves as the setting, reminding the viewer of a hotel room. The story begins abruptly without an introduction through a narrator or any dramatic elements, such as music or camera work. Viewers are confronted with two anonymous characters, about whom hardly any information is provided. Only the female character's clothing allows to draw conclusions about her age and social status. Wearing a school uniform consisting of a dark blue skirt and necktie, a white blouse and stockings, she takes over the role of a schoolgirl. Her look is completed by discreet make-up and loose, brownish dyed hair. Whereas she is being called Ami-chan throughout the film by her male counterpart, the around 40 -year-old male character is neither being introduced by his name nor does he share the same visual presence compared to the female character, who is shown extensively. Only a few glimpses can be caught of the male character's face and of individual body parts. He is undressed for the most

22 The porn films were chosen by their release years (from 2010 until 2015) and their categorisation on the websites (which help finding films with similar contents and characters' constellations).

23 The mainstream pornographic film was accessed at http://www.pornhub.com/view_video.php?viewkey =794253760; accessed July 2015 .

24 Creampie describes the sexual practice of an intravaginal ejaculation without using a condom.

25 Squirting describes the sexual practice of a strong intravaginal massage that leads to the ejaculation of the woman. 
part and wears nothing but black underpants, which makes it impossible to classify his social status or identify his profession.

Analysing the mainstream pornographic film, 16 sequences containing 91 shots were recorded. ${ }^{26}$ The sequences show different sexual contents and could therefore be divided into three groups: ${ }^{27}$ sequences that display sexual foreplay, ${ }^{28}$ oral sex, ${ }^{29}$ and vaginal sex. ${ }^{30}$ Measuring each group's duration, sexual foreplay is displayed for 17 minutes, followed by oral sex for 14 minutes, and vaginal sex for ten minutes. For a basic overview, the 16 sequences' main contents are summarised: In the first sequence, both characters are shown sitting on the bed; the male character is behind the female and touches her dressed body. He spreads her legs, massages her genital area, and asks her to touch herself. Only two minutes after the film started, the male character begins fingering the female character. The camera is focused on the female body and shows the male protagonist only partially.

In the second sequence, the female breasts play the most important role, followed by a focus on the female bottom in the third sequence. After taking off the female protagonist's blouse, the male protagonist touches, massages, kisses, and sucks the female breast, which produces a slurping sound. After licking her ear, followed by an intense French kiss, the male character initiates a change of the bodies' positions so that the female character is kneeling on all fours. Her bottom is exposed to the camera's focus, while the sideways positioned male character massages her genital area and thighs from behind. After an abrupt change of the camera's perspective, the undressed bottom of the female character is being focused. The male protagonist massages and licks the anus of the female character, who remains passive and quiet, aside from some moaning. Aside from adding the sexual practice of fingering, the fourth sequence shows overall the same contents as the third one does.

In the fifth sequence, the male protagonist initiates another change of the bodies' positions. Both characters stand on the bed next to each other. While the female protagonist holds her skirt up to the height of her belly, the male protagonist starts fingering her vagina quickly and intensively - a sexual practice called squirting. The female character emits vaginal discharge on the camera's screen while moaning loudly. In the sixth sequence, another change concerning the bodies' positions is carried out. The male protagonist lays down on his back and the female character sits down on his chest with spread legs, so that her genital area is positioned right in

26 Detailed information on the sequences' contents can be found in the Appendix of my M.A. thesis (Helm 2015: 114-130 and table 6).

27 The same categories are being used for the analysis of the women's pornographic film.

28 Sexual contents that were subsumed under the term 'sexual foreplay' are kissing, touching and massaging the genital area, touching other body parts (such as the breasts), or fingering.

29 Oral sex practices are cunnilingus, fellatio, and the sex position 69, which combines cunnilingus and fellatio.

30 Vaginal sex includes all forms of vaginal penetration. 
front of his face. The male character starts performing oral sex to his counterpart, which produces a slurping sound. In the following seventh sequence, he pushes her back slightly so that she lays on his chest and belly. In this position he begins fingering her vagina again. The camera focuses her genital area throughout the sequences, whereas the depiction of the male protagonist plays a secondary role. In the eight sequence, another positions' change is initiated by the male character. While he stands on the bed, the female protagonist sits in front of him, her face at the height of his genital area. She kisses and touches the dressed male genitalia.

In the ninth and longest sequence (four minutes and 30 seconds), the sexual practice of fellatio is shown in a very detailed way. The male genital area ${ }^{31}$ and the female protagonist's face dominate the shots' contents. The camera takes over the male character's perspective several times and shows the female character from a top view. In the course of this sequence an abrupt change of the camera's perspective occurs, as the female character is displayed in a lying position, while the male character penetrates her mouth in a straddle position. Two variations of oral sex, showing the sex position 69, are shown in the tenth sequence. Starting with the eleventh sequence and till the end of the film, diverse variations of vaginal sex are displayed. About eight different sex positions are depicted in the last six sequences of the film, including positions such as doggy-style and reverse-cowgirl. In the sixteenth and last sequence the intravaginal ejaculation (creampie) and the ensuing camera's focus on the outpouring sperm is dominating the shots' contents.

Next, the film's main contents will be analysed with the help of the Western characteristics of mainstream pornography. The selected film can be described as a typical representative of the genre, although it does not contain sexual practices such as anal sex or a visible ejaculation, nor does it show characters' constellations such as orgies or ménage à trois, as is the case in many mainstream pornographic films. The film corresponds to mainstream pornography's characteristics regarding both conceptual and aesthetic aspects as well as in terms of contents. Concerning narration, story, and introduction, it can be said that they are all absent: Only the school uniform of the female protagonist makes it possible to embed the sexual actions into a broader social context: a mature and dominant male encounters a young, subordinate, and immature female. Besides that, the contents of the film are reduced to a series of sexual actions, which are realised by anonymous and interchangeable characters. The viewer is being confronted with sexually explicit contents from the very first moment, and no introduction helps to initiate these sexual actions. The one-sided focus on the female protagonist's body suggests that the film is directed at a target group of male viewers.

31 After the male character has expressed his desire to take off his underpants, the female character helps him to do so. 
Dialogues between the characters are related to nothing more than their sexual relation and, therefore, appear to be emotionally distanced and artificial. The male character uses repeatedly the word sugoi 凄い (great or fabulous) to comment on sexual actions, and also verbalises his actions towards the female character. He, for example, comments on inserting his finger into her vagina (9th shot), asks her several times if she enjoys his touches (e.g. 9th, 20th, and 36th shot), or gives her instructions on how to change her body position (30th shot). The female character responds to his questions, but does not articulate herself independently. She uses mostly the words ii いい (“good”), or kimochi ii 気持ちいい (“it feels good”) to answer the male character's questions (3rd and 36th shot).

Mainstream pornography's typical aesthetic elements such as primitiveness, roughness, and nastiness play a dominant role in the film. Although the perception and evaluation of these elements might be subjective to a certain extent, some of the contents can clearly be described as being primitive or ugly. The male protagonist, for example, shows sexually unrestraint behaviour and is displayed as being driven by his lust, whereas the female protagonist plays a stereotypically passive role. Primitiveness is mainly realised by a one-sided voyeurism concerning the female character's body. By displaying the female pubic area, genitalia, and breasts she is being reduced to her sexual functions, while excluding the emotional and individualistic dimension of her personality. The camera focuses on the female body in a superficial and one-sided way making her appear like a sex object. Nastiness plays a major role regarding the display of sexual contents. Shots that show saliva dripping from the female protagonist's mouth when performing oral sex to the male character, or slurping sounds produced by the male protagonist while performing oral sex to the female character can be described as being nasty and ugly. Also, the sexual practice of squirting, which here is realised by the visible female ejaculation on the camera, demonstrates nastiness that is typical to mainstream pornography. Additionally, the 90th shot can serve as an example of the rawness of mainstream pornography's sexual contents, as the female character's vagina and the slowly outpouring sperm after the intravaginal ejaculation is being displayed in extreme close-up.

Concerning the camera work, it can be said that the film's contents are shown from the male character's perspective, which might support the sexual satisfaction of male viewers. For example, in the 9th shot, the female protagonist is shown from the male protagonist's perspective while performing oral sex. In this scene she maintains eye contact with the male character, which produces the impression that she looks directly at the viewer himself/herself. Therefore, the female character appears to be the object while the male character (or the viewer) takes over the role of the subject. The subject-object-hierarchy is not only produced by the camera's perspective but, in other instances, also by the subordinate behavior of the female character, who keeps her eyes lowered or even shut while being touched or penetrated by the male character. This passive behaviour gives the impression that she is absent- 
minded. Furthermore, the characters do not share the same kind of visual representation within the film, as the female body is being focused in a one-sided way. The male character's body is never fully being shown throughout the film and, therefore, can be described as being anonymous. Only individual body parts, like his hands (7th shot), his back, his legs, or parts of his head or face (8th shot) are displayed. The limited visibility of the male protagonist might also be in the interest of male viewers, who can take over his place in their imagination.

When analysing the film in relation to Faulstich's criteria of mainstream pornography it can be said that the film's contents are explicitly detailed, narrated, and fictionally real. Dialogues are focused on sexual aspects, and the characters are interchangeable (besides their age difference), as they lack any individualisation. The visual as well as verbal dimension of the film is limited to sexual contents, which are displayed in a fictionally real way through showing sexual practices and genitalia in extreme close-ups. The so-called money shot (visible ejaculation) is a very typical characteristic of mainstream pornography, but is not part of the selected film. Instead of a directly visible ejaculation, the climax is made visible later through showing the outpouring sperm for around 20 seconds. The focus on the male ejaculation differentiates the unimportance of the film's beginning from the importance of its ending, as the male climax appears to be the content's highlight. The sperm is being celebrated as a symbol for the fulfilment of the male (protagonist's) sexual satisfaction. As soon as the ejaculation occurred, both characters fade into the background like insignificant players, who are being reduced merely to their physiological functions. The male protagonist disappears entirely after his orgasm, whereas the female protagonist is displayed as an object that is keeping and presenting the sperm. The film's contents are also structured, and scenic narrative elements, such as the camera's perspective, draws the viewer's attention to the sexual contents, which are displayed in extreme close-ups, close-ups, and close shots. The camera's focus makes it impossible for the viewer to be distracted by other contents.

The comparison of the sexual practices' duration can help to draw conclusions about the film's correspondence to mainstream pornography's characteristics. When analysing the duration of fellatio and cunnilingus it can be found that the former is displayed for around four minutes, in contrast to cunnilingus which is displayed for around two minutes. Also, the female protagonist is shown for around five minutes being fingered from behind while kneeling. These contents are obviously meant to stimulate male heterosexual viewers as the target group of mainstream pornography. A contradictory aspect can be found concerning the balance between petting and penetration, as the former is being displayed for longer time. This contradiction to mainstream pornography's characteristics has to be relativised, though, when analysing the contents in a more detailed way, taking into account the camera work. In the selected film petting serves more the male viewer's sexual satisfaction than the purpose of sexual foreplay itself. The one-sided presentation of the female body, like 
showing the breasts, pubic area, and the bottom in extreme close-ups and close shots mainly support the male lust. The female character's masturbation is shown twice, which is also a typical element of mainstream pornography. Safe sex is not being practiced, which is quite common in mainstream porn. The male climax plays a major role, although the ejaculation cannot be seen directly. However, the male protagonist's orgasm is the highlight of the story, which corresponds to mainstream pornography's characteristics. It remains unclear if the female protagonist experiences an orgasm in the 28th and 29th shots. Her potential orgasm does not play any role in the film. All in all, it can be said that the displayed sexual practices correspond to mainstream pornography's characteristics as they are displayed to serve the male viewers' sexual satisfaction.

The film's protagonists show similarities to typical characters of mainstream porn, as their bodies appear to be fully functioning and driven by lust. The female character is young, slim, has long hair, and well-formed breasts. She wears white underpants that can be described as lingerie. Besides that, she does not really correspond to the mainstream pornography's characteristics. She wears only discreet make-up and does not have a clean-shaven pubic area, an attribute she shares with the male protagonist. The male character's sexual potency seems to be above average and, in scenes that show oral sex, his penis appears to be large. Regarding the characters' representations in the film it can be said that their bodies' sexual functions play the most important role for their identities.

Analysing the gender roles displayed in the film it becomes obvious that a conservative attitude towards masculinity and femininity is shown. The male protagonist takes over an active and leading role in terms of content. He acts as a father figure, who is superior to his female counterpart, by giving her instructions. His superiority is not only displayed by his leading role, but also by his dark voice and the verbal expressions that tend to sound patient, determined, and dominant at the same time. The female character, by contrast, takes over a passive, obedient and subordinate role, and acts as an immature and insecure schoolgirl. Her inferiority is displayed by her uncertain body language, childlike voice, ashamed facial expressions, and quietness. She expresses herself verbally only when asked by the male character.

The male character plays also a superior role because of his advanced age, whereas the female character is being expected to obey him as she has a lower social standing by acting as a schoolgirl. Furthermore, the male character's sexuality is being emphasised whereas the female character's sexuality seems to be following his. The female protagonist's sexual desires are not being discussed or shown, unless she is being asked explicitly by her counterpart to express her lust. The male character asks her several times if she feels sexual pleasure by his touches and actions, which she answers in a positive way invariably. Over time, the viewer might get the impression that the male protagonist's questions (for example in the 20th and 26th 
shots) are not based on empathy, but rather derive from the egoistic wish for selfaffirmation as the female body serves as object of projection of the male character's sexual lust. She keeps confirming her sexual pleasure if asked so and, in this context, the female body's signals, like vaginal discharge (10th shot), can be interpreted as further affirmations of the male character's sexual potency. This interpretation derives from the male viewers' tendency to identify themselves with the male protagonist and his lust. Therefore, the male character's self-affirmations are being transferred indirectly to male viewers.

Additionally, the subject-object-hierarchy between the characters is being supported by camera perspectives that expose the female body in a one-sided way. The female protagonist corresponds to the character type of a 'soiled virgin': Both her white underpants and the extensive and repeated focus on the insertion of the tongue or the penis into the female body throughout the film show that she takes over a clichéd innocent and originally virgin-like role, whereas the male protagonist plays the role of conqueror. The one-sided focus on the intravaginal ejaculation supports the image of the soiled virgin as well. Overall it can be said that, apart from the subject-object-hierarchy between the characters, both of them represent stereotypical and conservative gender roles.

\section{Female-Friendly Porn on the Internet: H.Net Free Porn Videos for Girls}

When searching the Internet for Japanese women's porn it becomes apparent that the target group of female viewers seems to be relatively new. Interestingly enough, quite many websites (a specific number cannot be determined) do concentrate on offering porn directed at women. Looking at some of these websites and their design, many differences between the ones that offer mainstream porn and the ones that offer women's porn become evident. As mentioned in the section "Film Selection", I chose the women's pornographic film First Touch from the Japanese website H.Net Free Porn Videos for Girls, which I will introduce in this section. ${ }^{32}$

As the Japanese title of the website reveals, it is directed at female viewers of pornography: josei no tame no muryō adaruto dōga ecchi netto 女性のための無料 アダルト動画エッチネット. By 2015-16, it offered around 1,000 free pornographic films for women via streaming. H.Net obtains the films from several websites, such as Xvideos, FC2, and Redtube, which also offer foreign productions. Selected films are chosen from these websites and are uploaded and assigned to certain categories. A menu bar containing five items is available for the website's viewers for better navigation: shinchaku 新着 for recently published films; ninkijun 人気順 for a ranking order according to previous consumers' requests; kindan 禁断 for films that

32 All information in this section are based on the contents of the website H.Net Free Porn Videos for Girls, which is available at http://xn--h-k9tybb8g5ivhkczry701afhpm4sru6d.net/; accessed on 15 June 2015. 
contain potential taboo subjects, such as homosexuality, sex in public, or quick sex; chōjikan 長時間 for films that last 40 minutes or longer; and ikemen イケメン for films featuring famous and handsome actors. Further categories help to find more specific contents, such as massāji マッサージ for sex with massage-elements, muriyari 無理やり for forced sex, surōsekkusu スローセックス for slow sex, raburabu ラ ブラブ for sex between a courting couple, boisu rabu ボーイズ ラブ and rezu レズ for homosexual sex, or nakadashi 中出し for sex with an intravaginal ejaculation. Although sexual plurality is a Western criterion for women's pornography, it must be stated that H.Net Free Porn Videos for Girls does not take this criterion into account as it declares homosexuality as taboo subject. Furthermore, the category muriyari might oppose a women-friendly attitude, as forced sex can be linked to violent behaviour towards women. On the other hand, this category could also display a tolerant and sex-positive attitude regarding women's diverse sexual fantasies.

The website's design is customer-oriented. A light pink was chosen as its dominating colour, and other feminine elements were added. For example, a black ribbon frames the contents of the homepage and, additionally, a black lace border crosses the upper part of the website's pages from left to right. H.Net Free Porn Videos for Girls has its own mascot, a cartoon figure with cat's ears, a tail, wearing black lingerie. A series of screenshots gives an overview of the films and their contents, followed by a synopsis and details concerning the duration and the date of publication. Sexually explicit contents and genitalia on the screenshots are censored by the application of pink hearts, and the films' sexual contents are also blurred. These aesthetic elements differ from mainstream pornographic websites' average designs.

\section{Analysis of a Japanese Women's Pornographic Film}

The contents of the 43 minutes long women's pornographic film First Touch are censored. Tags such as oshare おしやれ for elegance, ikemen dan'yū イケメン 男優 for handsome actor, sawayaka ikemen 爽やかイケメン for eloquent and handsome man, bidanshi 美男子 for handsome man, dorama fū ドラマ風 for a style that reminds of a television drama, raburabu ecchi ラブラブ for sex between a courting couple, tomodachi to ecchi 友達と for sex with a friend, honban 本番 for real and non-simulated sex, and surō sekkusu スローセックス for slow sex serve as descriptions for the film's contents.

The story of the film is revealed by a headline that summarises the contents in a few sentences. The film is about two school friends who celebrate their reunion after some time in the apartment of the male character. Time flies by and the female protagonist's last train departure comes closer, when the two friends fall asleep on the sofa unintentionally. As they wake up again they realise their mutual attraction 
and decide to spend the night together. The living room and the bedroom of the apartment serve as the setting and create a familiar atmosphere by the decoration that includes plants, personal items (like photographs, pictures, books), and wooden furniture. The film begins with three initial sequences that show the two characters talking to each other in the living room while sitting on a sofa. The conversations' contents as well as the settings' atmosphere serve to introduce the characters and the story to the viewer. The female protagonist is a young woman in her twenties, wearing a long skirt and a cream-coloured pullover. Her look can be described as natural. Her hair is knotted to a bun with loose strands of hair hanging onto her face and she has discreet make-up. The female protagonist is being called Aya-chan, which is very likely an abbreviation for the porn actress's name Tomoda Ayaka 友田彩也香, who plays the female character. The male protagonist is portrayed by the porn actor Suzuki Ittetsu 鈴木一徹 and can be described as a charismatic and humorous young man in his late twenties. He wears blue jeans, a white long sleeved shirt, and has a stylish haircut.

A closer analysis of the women's pornographic film revealed that it can be divided into 14 sequences and in 140 shots, which are noted in detail in the Appendix of my M.A. thesis (Helm 2015: 130-180). In addition to the already established sequence groups 'sexual foreplay, oral sex, and vaginal sex', another group of sequences featuring non-sexual contents shall be added under the term 'platonic relation'. Measuring each group's duration, the contents of First Touch can be divided into three minutes showing the platonic relation, 15 minutes of sexual foreplay, five minutes of oral sex, and 18 minutes of vaginal sex. The sequences' main contents are: In the first one, the encounter of two old school friends is displayed. While they are sitting on a sofa, they talk about their memories, drink red wine, and eat small snacks. Both characters are in a good and talkative mood, which is being supported by cheerful piano music and varied camera perspectives that alternately focus on the characters' faces during their conversation. A fade-out and the silencing of the piano music mark the end of the first sequence and the beginning of the second one.

In the second sequence, after a fade-in, the camera focus on the cleaned plates and drunk up wine glasses, followed by showing a wall clock's time, which gives the viewer the impression that some time must have gone by. Silence enforces the contrast between the initial sequence's vivid atmosphere and the second sequence's standstill. After another fade-out and fade-in, the two protagonists are displayed while leaning and, at the same time, falling asleep on the sofa. As the female character awakes, she realises the late time and the approaching departure of her last train. She decides to wake up her friend, who is sleeping calmly. While watching and talking to him with a gentle voice, romantic piano music starts. The music ends abruptly as the male protagonist suddenly opens his eyes. 
In the third sequence, the male protagonist hugs his friend passionately and asks her feelingly if she really needs to leave. The female protagonist finally admits that she would like to stay and they start kissing. The male character's lust grows and he pushes the female protagonist to lay back on the sofa. As he starts touching her breast she interrupts him and insists on using the bathroom before they continue. The scene is accompanied by romantic piano music. At the end of the third sequence, it becomes obvious for the viewer that the characters are going to spend the night together. The fourth sequence is introduced by several fades, which show the characters getting up from the sofa, details from the apartment and, finally, the bedroom. The male protagonist sits on the bed waiting for his friend. He has changed his clothes and wears a white T-shirt and black convenient trousers. The female protagonist enters the room, also wearing a white T-shirt. After having been invited over to sit with him on the bed, she asks him to dim the lights. They kiss each other and he confesses his love to her. The foreplay is accompanied by gentle piano music, which ends with this sequence.

In the fifth sequence the characters decide to undress. The female protagonist shows some hesitation to do so, but is encouraged by repeated compliments from her friend. He starts kissing the female character's bare skin and breast and recognises that her body is covered with many birthmarks, which he starts to kiss tenderly. Finally, the male character gets undressed and lays down on her body. In the sixth sequence, the male protagonist starts touching her pubic area. The camera switches between medium long shots of the bodies, close shots of the faces, and full shots that all dominate the fifth and sixth sequence (Helm 2015: 84-85). In the seventh and eighth sequence oral sex (cunnilingus) is displayed, which is accompanied by the female's protagonist moans of pleasure. Additionally, in the eighth sequence fingering and a combination of cunnilingus and fingering is shown. The female character repeatedly expresses her lust. The camera work mainly consists of displaying the characters' faces and bodies in close-ups and close shots, while position changes are realised by full shots and medium long shots.

In the ninth sequence, a transition from oral sex to vaginal sex is carried out. The male protagonist gets prepared by taking off his black pants and slipping on a condom. Starting with the tenth sequence, vaginal sex in diverse variations is displayed. Especially the beginning of the vaginal penetration in the tenth sequence is displayed in a detailed way, showing both character's lust and passion. Moans of pleasure become a lasting acoustic element till the end of the film. Medium long shots are used to display the bodies, and close-ups of the faces enable the comprehension of the characters' emotions. The positions' transitions are always initiated by the male character. In the fourteenth and last sequence, the male protagonist's ejaculation is shown in a detailed way: In this final scene the moving bodies' naked skin produces a smacking sound through the penetration, which is accompanied by puffing and moans of pleasure. Finally, the male protagonist asks the female charac- 
ter for her permission to have an intravaginal ejaculation, which she accepts. After the orgasm the characters remain exhausted in their positions, mutually expressing their feelings. In the last shot, the protagonists are shown while playfully kissing, which is accompanied by the first sequence's cheerful piano music and the camera's zoom out. The film ends with a final fade-out and a caesura of the piano music, which is followed by showing the film credits.

The presence or absence of a story constitutes one of the main differences between mainstream and women's pornography. A story makes it possible to embed the sexual encounter in a broader interpersonal relation's context. First Touch does not only tell a story that plays in a carefully created setting, but also introduces its characters through their appearance, behaviour, and dialogues. Surprisingly, the film does not start with an artificial introduction that solely serves the purpose of initiating the sexual contents, as it would be common in mainstream pornography. On the contrary, the beginning conveys an authentic and realistic introduction to the story. Whereas the sexual character of mainstream pornographic films is obvious from the very first moment as naked bodies and sexually interacting characters are shown, unsuspecting viewers who watch the introduction of First Touch for the first time could initially perceive it as a non-sexual film. The fact that a three minutes long dialogue between two former school friends, who maintain a platonic relation, is displayed indicates that this film was not produced for a fast consumption of sexually satisfactory contents.

The presence of a story can also be evaluated by taking into account the development of the interpersonal relationship between the characters. Their initially platonic friendship develops in the third sequence into a passionate mutual attraction, which appears to be based on sympathy rather than on pure sexual desire. Verbal expressions of love and compliments support the viewer's impression that an interpersonal relationship that goes beyond sexual interest is constructed here-in other words, the dialogues do not only serve the development of the story's sexual components. The following examples illustrate the non-sexual aspects of the characters' conversations: In the 45th shot, the male protagonist asks his female counterpart if her hesitation to get undressed might come from her shyness. Thinking about the underlying motivation of this question, it becomes clear that it rather expresses the male protagonist's empathy than merely his sexual interest. Furthermore, in the 19th shot, the male character's question concerning the female protagonist's return by train gives her the opportunity to choose between going home and staying at his place, which would not necessarily include sexual intercourse. In case he had not asked, she probably would have been too shy to ask herself. This scene reflects the male protagonist's skill to show his empathy without being obtrusive. Finally, in the 138th shot, the development of the characters' interpersonal relationship reaches its peak as both protagonists confess their love to each other. 
Concerning the film production's components such as setting, camera work, and sound, differences between conventional mainstream pornography and the analysed women's pornographic film become obvious. An effort to use diverse settings for the filming can hardly be found in mainstream pornography's production, but in First Touch two nicely decorated rooms serve as settings. Further details, such as the possibility to dim the light in the bedroom, might also be appealing to the target group of female viewers, as it creates a romantic atmosphere in opposition to mainstream pornography's hard light, which is thrown on exposed genitalia. Regarding the camera work, First Touch offers more diversified perspectives than the discussed mainstream pornographic film. Contrary to conventional mainstream pornography, extreme close-ups are not being used. The display of the emotional interpersonal relationship is emphasised by close shots and close-ups, which can be interpreted as avoidance of one-sided expositions of naked bodies and genitalia, which are common in mainstream pornography. Music and sounds in First Touch fit the contents and rather support the story than the sexual actions. Cheerful piano music is being used as background of the story both in the beginning and at the end, romantic and dreamy piano music accompany emotional scenes, and during the main part of the film the renunciation of music supports the naturalness of the sexual contents. Contrary to this, in many mainstream pornographic films monotone music is being provided as background for the penetration of the female character. In First Touch body sounds play a minor role and are not being emphasised.

Analysing the sexual contents of First Touch (which was selected to find out whether Japanese women's pornography exists according to Western criteria) it can be found that sexual practices, such as group sex and anal sex, are being avoided, the practice of fellatio is not shown at all, whereas cunnilingus plays a dominant role within the film. Hence female pleasure is the focus of attention. The male protagonist does not only articulate his own pleasure while performing oral sex to the female character (63th shot), but also watches her reaction. In the 66th shot, for example, he asks her if the pressure of his tongue is too hard, which reflects his attitude towards the importance of her sexual pleasure and satisfaction. Furthermore, the absence of fellatio, which is a very common sexual practice in mainstream pornography, can be interpreted as a conscious choice on the part of the producers to oppose male-centered sexuality. The common one-sided focus on the male genitalia is avoided throughout the film, and the display of genitalia is generally being limited to a few scenes. The practice of safer sex is initiated by the male character, whose penis is not even shown when slipping on the condom. The visibility of the male protagonist's erect genitalia is also prevented by the intravaginal ejaculation. One of the criteria of women's pornography is the avoidance of putting an emphasis on the orgasm of the male character. In First Touch the preparation of the male protagonist's climax is displayed over seven minutes (in the fourteenth sequence), which contradicts the women's pornography's criteria not to merely lay emphasis on the 
male character's orgasm. Additionally, the male character's climax is being used as a dramaturgic element to mark the end of the film, which is a common element in mainstream pornography. While these contents contradict women's pornography's criteria, the detailed display of the male protagonist's orgasm can also be interpreted as sex-positive attitude on the part of the producers. The actor has the freedom to take the time that he needs to experience an orgasm without restraints (137th shot). Moreover, the emotional ending of the film enables the embedding of the sexual contents into an overall interpersonal context, as the characters are shown laughing and kissing, which weakens the impression that the film is merely focused on sexual contents.

Regarding the characters, it can be found that neither the female nor the male protagonist is being individualised to a great extent. Both protagonists are attractive and correspond to general societal ideals of beauty and aesthetics. They have wellshaped bodies, attractive faces, and are dressed in a stylish way. However, some characteristics of the protagonists can be interpreted as meeting women's pornography's criteria. The female protagonist, for example, represents a natural beauty, and the explicit display of her birthmarks can be perceived as the producers' attempt to introduce an alternative model of beauty to the viewers. Furthermore, the female character's body is not being presented as sex object to please male viewers' sexual desires. The protagonists share an equal visual representation within the film, unlike the characters of the example of mainstream pornography analysed above. The male character corresponds to women's pornography's criteria in so far as he deviates from stereotypes, such as the rapist or the conqueror, which are frequently used in mainstream pornography. Also his behaviour distinguishes him from mainstream pornography's male characters. He expresses his feelings openly, treats the female protagonist respectfully and nicely, and tries to please her sexually. His rather passionate behaviour at the beginning of the film, when discovering his attraction to the female protagonist, might cause the impression of him taking over a dominant role. This is being relativised by his further actions, as he plays a rather caring and tender role.

The analysis of the gender roles represented in First Touch shows that both characters seem to be represented in terms of conventional gender roles. The male protagonist takes over an active role regarding sexual actions and initiates the sex positions' transitions, while the female protagonist follows his instructions and appears to be sexually reserved and passive. She only shows initiative that is not connected to sexual contents. For example, she chooses to stay at the male protagonists place overnight (21st shot), insists on using the bathroom before proceeding with sexual actions (31st shot), and convinces the male character to dim the lights in the bedroom (38th shot), although he refuses to do so initially. Although the female protagonist does not take over an active role in sexual actions, she articulates her sexual satisfaction many times and comments the sexual climax (in the 137th shot) 
with the words issho ni $i k u$ 一緒に行く, which means 'I am coming with you'. On the one hand, this expression can be interpreted as an effort to support the male protagonist's sexual satisfaction, which would correspond to mainstream pornography's characteristics. On the other hand, it can also be interpreted as verbal expression of the female protagonist's own sexual satisfaction, through which the female orgasm becomes perceptible for the viewer. The latter interpretation corresponds to women's pornography's criteria to place the female pleasure and orgasm at the center of the sexual actions. Furthermore, although the male protagonist corresponds to stereotypical characteristics of masculinity in decision-making regarding the sexual aspects, he also displays a caring, tender, and empathic behaviour that is not conventionally considered being masculine. Compared to the characters in mainstream pornography, the male protagonist of First Touch especially represents a different and more complex male role by expressing his feelings openly and putting emphasis on the female's sexual pleasure, which is a major criterion of women's porn.

\section{Conclusion}

The analysis of the selected Japanese mainstream and women's pornographic film has yielded that many differences between these two genres can actually be discovered. The most significant deviations can be found regarding the contents and their ideological background: The mainstream pornographic film is directed at a male viewers' target group, displays the female body as sex object, and focuses on sexual contents without telling a story. The women's pornographic film, by contrast, shows an interpersonal relationship between the characters that is developing throughout the story. Female friendly sexual practices are being focused, and the female's sexual pleasure plays a dominant role. Characters' dialogues also differentiate the genres from each other: Whereas verbal expressions within the mainstream pornographic film are being used to support the sexual contents, the women's pornographic film contains dialogues that exceed the sexual dimension and mirror an interpersonal relationship between the characters. Emotional expressions and love confessions show the characters' intimacy. Dialogues that are part of the sexual contents tend to be one-sided in both films: the male character in the mainstream pornographic film expresses his sexual pleasure more often than the female character, and it is exactly the other way round in the women's pornographic film. This might be explained by the genres' assumed target groups that are male in the one case and female in the other.

The analysis of both films' sexual contents also shows differences between mainstream and women's pornography: Although sexual foreplay takes on a comparatively equal role in both films when considering the duration, its contents are 
very different. The mainstream pornographic film's foreplay focuses on the display of the female body, whereas the women's pornographic film puts an emphasis on emotions, tenderness, affection, and dialogues. Furthermore, differences between the function of the displayed oral sex can be found. Although oral sex is shown for only five minutes in First Touch, it concentrates and focuses on the practice of cunnilingus and the female pleasure. The oral sex displayed in the mainstream pornographic film is more varied and seems to play a more dominant role in general. Regarding the correspondence to the Western characteristics of mainstream porn and women's porn, it can be said that both films focus on sexual practices that are supposed to satisfy their target group.

Not only the contents of both genres are different, but also the camera work, the setting, and the music/sounds. The camera work within the women's pornographic film is more differentiated as perspectives switch between medium long shots and full shots on the one hand, and close-ups and close shots on the other. In the mainstream pornographic film, extreme close-ups, close shots, and close-ups play the most important role. Regarding both films' settings, it can be said that the producers of the women's pornographic film put more emphasis on the display of a personalised and authentic setting that might be appealing to female viewers, whereas the setting of the mainstream pornographic film is being kept simple by showing an anonymous room that is equipped solely with a bed and a lamp. When analysing the sounds and the music of both films, major differences become evident. In the women's pornographic film music is being used to support the non-sexual contents, while sexual contents are shown without any music and without putting an emphasis on body sounds. In the mainstream pornographic film, on the contrary, body sounds play a very important role to support the sexual contents, whereas music is not being used at all.

To summarise the findings regarding the depiction of both films' characters, it can be said that the mainstream pornographic film's protagonists are being reduced to their sexual functions and performances, and that they are displayed as being interchangeable. The male character is shown as an anonymous body and remains almost invisible throughout the film. His sexual potency is his most important feature. The female character plays a stereotypical role of a subordinate sex object that serves the male sexual satisfaction, and thus also acts in the role of a soiled virgin. The women's pornographic film's characters, by contrast, are introduced as individuals that have an interpersonal emotional relationship. The male protagonist takes over the role of a caring and tender lover, who spares no effort to please his female counterpart both sexually and emotionally. He equally shares the visual presence with the female protagonist. She does not deviate from a conventional female role, although she proves some strength in decision-making and assertiveness. Furthermore, her body is displayed as representing an alternative beauty through the emphasis that is being put on her birthmarks. This aspect corresponds to 
the women's pornographic film's criteria, demanding to also show bodies that deviate from conventional beauty ideals. Concerning the display of male sexuality, it can be said that both male protagonists take over a stereotypical role through being the initiators of sexual actions. The female characters, by contrast, play a clichéd passive role and do not take the initiative in their sexual relations.

The analysis has yielded that the film examples taken from two different genres of pornography are overall in accordance with their Western counterparts. Furthermore, the Japanese women's pornographic film corresponds to PorYes feminists' demands regarding pornography, as it displays an emotional interpersonal relationship between individualised characters and it focuses on female sexual pleasure. Concerning the gender roles in First Touch it can be said that the female protagonist does not mirror a progressive or unconventional female role, whereas the male protagonist shows tendencies of dissolving stereotypical male gender norms. Apart from that, the Japanese women's pornographic film supports a sex-positive attitude, which is demanded by ProYes feminists: Sexual actions that support female sexual pleasure are being the focus, and the male protagonist has the opportunity to experience his orgasm freely and without pressure. PorNo feminists' criticism about mainstream pornography overlaps with the results of the analysis, as the female protagonist of the mainstream pornographic film takes over the role of a sex object that serves the male character's sexual satisfaction.

Japanese women's pornography has emerged on the Internet and attracts a relatively new target group of female viewers, who have certain demands that are not being met by mainstream porn. Further research on these new consumers will be needed in order to find out more about their consumer behaviour, motives, and needs. Women's pornography has the potential to replace stereotypical gender roles by more progressive ones, such as the male character in First Touch, who concentrates on his partner's pleasure rather than on his own, and who is supportive towards the establishment of an interpersonal relationship that is not merely tied to sexual actions. The analysis of these films will help to identify recent societal developments regarding gender representations and gender relations in Japan. The transformation of the male and the female gender role, as well as the focus on female sexuality in women's pornography might influence its female viewers. Therefore, women's porn does not only reflect its producers' ideas and viewers' desires, but also offers an opportunity to make these desires become part of women's real lives. Through investigating Japanese women's pornography and the gender roles it displays on screen, ongoing societal processes can be revealed, just before they might be realised off-screen. 
60

Vienna Journal of East Asian Studies

\section{LIST OF ABBREVIATIONS}

$\begin{array}{ll}\text { FPAs } & \text { Feminist Porn Awards } \\ \text { HN } & \text { H.Net Free Porn Videos for Girls } \\ \text { MM } & \text { Missy Magazine } \\ \text { PH } & \text { Pornhub } \\ \text { PYA } & \text { PorYes Award } \\ \text { SS } & \text { Safer Surfing }\end{array}$




\section{REFERENCES}

Bateman, Jessica. “A Real Alternative?” The F Word: Contemporary UK Feminism, 2007, http://www.thefword.org.uk/features/207/01/alternative, accessed July 2015

Dales, Laura. Feminist Movements in Contemporary Japan. London and New York: Routledge, 2009

Domenig, Roland. "Vital Flesh: The Mysterious World of Pink Eiga.” 2002, http://web.archive.org/web/20041118094603/http://194.21.179.166/cecudine/fe_2002/eng/Pin kEiga2002.htm, accessed July 2015

Dworkin, Andrea. "Ein Brief an alle Schwestern." In PorNo. Opfer und Täter. Gegenwehr und Backlash. Verantwortung und Gesetz, edited by Alice Schwarzer. Köln: Kiepenheuer und Witsch, 1987, pp. 129-154

Faulstich, Werner. Die Kultur der Pornografie: Kleine Einführung in Geschichte, Medien, Ästhetik, Markt und Bedeutung. Bardowick: Wissenschaftler-Verlag, 1994

Faulstich, Werner. Grundkurs Filmanalyse. Paderborn: Wilhelm Fink Verlag, 2013

Ferguson, Ann et al. "Forum: The Feminist Sexuality Debates." In Signs: Journal of Women in Culture and Society, 10/1, 1984, pp. 106-125

Flaßpöhler, Svenja. Der Wille zur Lust: Pornographie und das modern Subjekt. Frankfurt a. M.: Campus-Verlag, 2007

FPAs (Feminist Porn Awards). "The Feminist Porn Awards: How Did it All Start?" Feminist Porn Awards, 2016, http://www.feministpornawards.com/blog/the-feminist-porn-awards-how-didit-all-start/, accessed February 2016

Fujieda, Mioko and Kumiko Fujimura-Fanselow. "Women's Studies: An Overview.” In Japanese Women: New Feminist Perspectives on the Past, Present and Future, edited by Atsuko Kameda and Kumiko Fujimura-Fanselow. New York: The Feminist Press, 1995, pp. 155-181

Hahn, Kathrin. "Geschlechterkonstruktion im post-pornografischen Film. Weibliche Geschlechtsdarstellung anhand des Beispiels Shortbus.” M.A. thesis, University of Vienna, 2011, http://othes.univie.ac.at/15345/1/2011-06-03_0401791.pdf, accessed November 2015

Helm, Katharina. "Women's pleasure online - kontrastierende Analyse eines ausgewählten japanischen Mainstream- und Frauenpornofilms aus dem Internet." M.A. thesis, University of Vienna, 2015, http://othes.univie.ac.at/36672/1/2015-03-17_0807527.pdf, accessed September 2015

HN (H.Net Free Porn Videos for Girls). "H.Net Information.” Josei no tame no muryō adaruto dōga ecchi netto 女性のための無料アダルト動画エッチネット [H.Net Free Adult Porn for Women], 2015, http://xn--h-k9tybb8g5ivhkczry701afhpm4sru6d.net/, accessed February 2016

MM (Missy Magazine). “Team Sex. Was ist das 'Post' im Post Porn?” Missy Magazine, 2013, http://missy-magazine.de/2013/06/10/team-sex-was-ist-das-post-im-post-porn/, accessed February 2016

PH (Pornhub). "Japanese schoolgirl in uniform dicked and stuffed in her twat." Pornhub Network, 2014, http://www.pornhub.com/view_video.php?viewkey=794253760, accessed July 2015

PYA (PorYes Award). “Worum geht's?” PorYes. Check the difference, n.y.a, http://www.poryes.de/warum-poryes/, accessed July 2015

PYA (PorYes Award). "Hintergrund." PorYes. Check the difference, n.y.b, http://www.poryes.de/hintergrund/, accessed July 2015

PYA (PorYes Award). "FAQ." PorYes. Check the difference, n.y.c, http://www.poryes.de/frequently-asked-questions/, accessed July 2015

PYA (PorYes Award). "Jury." PorYes. Check the difference, n.y.d, http://www.poryes.de/jury/, accessed February 2016 
Rückert, Corinna. "Frauenpornografie. Pornographie von Frauen für Frauen: Eine kulturwissenschaftliche Studie." Ph.D. diss., University of Lüneburg, 2000

Schwarzer, Alice. PorNo. Opfer und Täter. Gegenwehr und Backlash. Verantwortung und Gesetz. Köln: Kiepenheuer und Witsch, 1994

Sharp, Jasper. Behind the Pink Curtain: The Complete History of Japanese Sex Cinema. Godalming: FAB Press, 2008

Shigematsu, Setsu. "The Women's Liberation Movement and Sexuality in Japan." In Routledge Handbook of Sexuality Studies in East Asia, edited by Mark McLelland and Vera Mackie. London and New York: Routledge, 2015, pp. 174-187

SS (Safer Surfing). "Statistiken Pornographie.” Nackte Tatsachen, eine Plattform zu Themen der Sexualität, Pornographie- und Sexabhängigkeit und Kinderschutz, 2015, http://www.nacktetatsachen.at/?id=455, accessed April 2015

Stiglegger, Marcus. "Genretheorie des Films 1. Filmgenres. Keynote zur Gattungspoetik des Films.” Ikonenmagazin, 2009, http://www.ikonenmagazin.de/artikel/Genretheorie_ Stiglegger.htm, accessed June 2015

Uchiyama, Ayako and Milton Diamond. "Pornography, Rape and Sex Crimes in Japan.” University of Hawai'i, 1999, http://www.hawaii.edu/PCSS/biblio/articles/ 1961to1999/1999pornography-rape-sex-crimes-japan.html, accessed July 2015 


\section{GLOSSARY}

adaruto bideo
anime/ animēshon
bidanshi
bōisu rabu
chōjikan
dorama fū
hentai

honban

ii

ikemen (dan'yü)

issho ni iku

josei no tame no muryō adaruto doga ecchi

netto

kimochi ii

kindan

Kōdō suru onnatachi no kai

massāji

manga

muriyari

nakadashi

ninkijun

oshare

pinku eiga

raburabu

raburabu ecchi

rezu

sanbondate

sawayaka ikemen

seijin eiga

shinchaku

shunga

sugoi
アダルト・ビデオ

アニメ(ーション $)$

美男子

ボーイズラブ

長時間

ドラマ風

変態

本番

いい

イケメン(男優)

一緒に行く

女性のための無料ア

ダルト動画エッチ

ネット

気持ちいい

禁断

行動する女達の会

マッサージ

漫画

無理やり

中出し

人気順

おしやれ

ピンク映画

ラブラブ

ラブラブ $\mathrm{H}$

レズ

3本立て

爽やかイケメン

成人映画

新着

春画

凄い adult video/AV

animated/comic film

handsome man

gay sex (male homosexuality)

long duration

a style that reminds of a television drama

often used as abbreviation for Japanese

animated pornographic films or porno-

graphic comics; abbreviation "H" (ecchi in Japanese) is also used for sex, for example 'ecchi suru' meaning 'to have sex'

in the context of this paper: real, non-

simulated sex

literally: good (adjective)

handsome man (actor)

literally: I am coming with you; phrase to

express the wish to experience a joined

orgasm

literally: free adult films' sex web for

women

literally: it feels good; phrase to express a good feeling

prohibition, taboo

Women's Action Group (= Japanese

feminist group)

massage

Japanese comics

force, pressure

intravaginal ejaculation

ranking order according to popularity

elegance, elegant

literally: pink movie; Japanese sex film without showing sexually explicit contents being in love

sex between a courting couple

lesbian sex (female homo sexuality)

tickets (for Japanese sex films) sold in

threes

eloquent and handsome men

literally: film for adults; sex film

in the context of this paper: a recent film

literally: spring pictures; erotic prints that

show sexually explicit contents

in the context of this

paper: great, fabulous, splendid 
64 Vienna Journal of East Asian Studies

surōsekkusu

tomodachi to ecchi

Ūman ribu
スローセックス

友達と $\mathrm{H}$

ウーマン・リブ literally: slow sex

sex with a friend

literally: Woman lib; abbreviation for

Women's Liberation Movement

(= Japanese feminist movement in the

1960s and 1970s) 